\title{
Sensitive and Selective Electrochemical Detection of Carbon Monoxide in Saline at a Pt-Ru/Nafion/ $\mathrm{MnO}_{2}$-Modified Electrode
}

\author{
Hirosato SETo,* Takeshi Kondo,*,** and Makoto YUASA*,**† \\ *Department of Pure and Applied Chemistry, Faculty of Science and Technology, Tokyo University of Science, \\ 2641 Yamazaki, Noda, Chiba 278-8510, Japan \\ **Research Institute for Science and Technology, Tokyo University of Science, 2641 Yamazaki, Noda, \\ Chiba 278-8510, Japan
}

\begin{abstract}
We fabricated a sensitive and selective electrochemical carbon monoxide (CO) sensor for physiological conditions based on the Pt-Ru system. At a bare Pt-Ru electrode, a linear amperometric response to CO concentration was obtained in the range of $0.9-9 \mu \mathrm{M}$. However, significant current response to model electroactive interferents for physiological conditions, uric acid (UA), ascorbic acid (AA) and hydrogen peroxide (HP), was also recorded at the Pt-Ru electrode. The response to UA and AA was highly suppressed by coating the Pt-Ru electrode surface with a Nafion layer, and the response to HP was almost completely eliminated by the additional coating with a $\mathrm{MnO}_{2} /$ chitosan layer. Finally, at the Pt-Ru/Nafion/ $\mathrm{MnO}_{2}$ electrode, amperometric $\mathrm{CO}$ detection with a sensitivity of $173 \mathrm{nA} \mathrm{cm}{ }^{-2} \mu \mathrm{M}^{-1}$ was obtained in the concentration range of $0.9-9 \mu \mathrm{M}$ with the UA, AA and HP signal being below $1.7 \%$ at the same concentration of CO.
\end{abstract}

(Received November 16, 2011; Accepted December 6, 2011; Published February 10, 2012)

\section{Introduction}

Carbon monoxide (CO) can be generated by incomplete combustion, which is often associated with silent asphyxiation if improper ventilation is not used. Additionally, $\mathrm{CO}$ is endogenously and physiologically generated in mammalian cells as a result of catabolism of heme in the rate-limiting step by heme oxygenase system. Recently, such CO systems have drawn attention due to their various essential roles in living bodies such as anti-inflammatory, antioxidant and antiapoptotic effects. $^{1-8}$ Researchers have employed several methods to study the effect of $\mathrm{CO}$ on living bodies by using heme oxygenase (HO-1) knockout mice ${ }^{9,10}$ and CooA-based biosensors, ${ }^{11,12}$ and by monitoring $\mathrm{CO}$ concentration indirectly from the breath. ${ }^{13}$ By these methods, however, it is difficult to measure $\mathrm{CO}$ concentration locally, in real time and in vivo, which would be highly beneficial for understanding the function of $\mathrm{CO}$ in living bodies. In this study, we have developed a sensitive and selective electrochemical sensor for $\mathrm{CO}$ in physiological conditions by surface modification of a Pt-Ru electrode. The $\mathrm{Pt}-\mathrm{Ru}$ system is known to be effective in the electrochemical oxidation of $\mathrm{CO}$ to $\mathrm{CO}_{2}$, while in the pure Pt system $\mathrm{CO}$ can be adsorbed strongly on the surface, causing serious poisoning. ${ }^{14-16}$ For the Pt-Ru system, oxidation of $\mathrm{CO}$ has been considered to occur via reaction between $\mathrm{CO}$ adsorbed on $\mathrm{Pt}$ sites $(\mathrm{Pt}-\mathrm{CO})$ and $\mathrm{Ru}-\mathrm{OH}$ species formed by discharging the adsorbed water (bifunctional mechanism). ${ }^{17}$ In addition, ruthenium can modify the electronic structure of platinum. This modification induces a weakening of the Pt-CO bond, lowering the energy required for the oxidation of the adsorbed $\mathrm{CO}$ on $\mathrm{Pt}$ (ligand effect). ${ }^{18}$ To

† To whom correspondence should be addressed.

E-mail: yuasa@rs.noda.tus.ac.jp improve selectivity of $\mathrm{CO}$ detection from possible electroactive interferents which are ubiquitous in a biological fluid, such as uric acid (UA), ascorbic acid (AA) and hydrogen peroxide (HP), we modified the Pt-Ru electrode surface with Nafion and $\mathrm{MnO}_{2} /$ chitosan layers (Fig. 1). Nafion can be act as a permselective membrane, which can exclude the diffusion of UA and AA. ${ }^{19,20} \quad \mathrm{MnO}_{2}$ is a well-known catalyst for HP decomposition into $\mathrm{H}_{2} \mathrm{O}$ and $\mathrm{O}_{2}$. Chitosan is a natural organic polymer with excellent properties for an immobilization matrix for a biosensor such as low cost, high mechanical strength, good film-forming capability, biocompatibility and nontoxicity. ${ }^{21-23}$ The modified Pt-Ru electrode showed sensitive CO detection in the physiological concentration range $(0.9$ to $9 \mu \mathrm{M})$, while it showed almost no current response to AA, UA and HP for the same concentrations to $\mathrm{CO}$.

\section{Experimental}

\section{Preparation of modified electrodes}

The Pt-Ru electrode was prepared by electrodeposition. A ruthenium thin film was first deposited onto a gold electrode (BAS, electrode diameter was $1.6 \mathrm{~mm}$ ) surface by applying a potential of $-500 \mathrm{mV} v s . \mathrm{Ag} / \mathrm{AgCl}$ in $20 \mathrm{mM} \mathrm{RuCl}_{3}$ at $40^{\circ} \mathrm{C}$ for $180 \mathrm{~s}$. The Ru-covered electrode was then subjected to platinum deposition in an aqueous solution containing $1 \mathrm{mM} \mathrm{H}_{2} \mathrm{PtCl}_{6}$ at a potential of $-200 \mathrm{mV} v s . \mathrm{Ag} / \mathrm{AgCl}$ at $40^{\circ} \mathrm{C}$ for $14 \mathrm{~s}$. The $\mathrm{Ru} / \mathrm{Pt}$ ratio of the electrode was determined by X-ray photoelectron spectroscopy (XPS; AXIS-NOVA, Kratos). For XPS analysis, the Pt-Ru samples were prepared on a gold wire. The binding energy was calibrated with the position of a $\mathrm{C} 1 \mathrm{~s}$ peak to be $284.8 \mathrm{eV}$. The Nafion-coated Pt-Ru electrode was prepared by casting a $7.1 \mu \mathrm{L} \mathrm{cm}$ cm $^{-2}$ of $2 \mathrm{wt} \%$ Nafion solution on the Pt-Ru electrode. The $2 \mathrm{wt} \%$ Nafion solution was prepared by diluting 


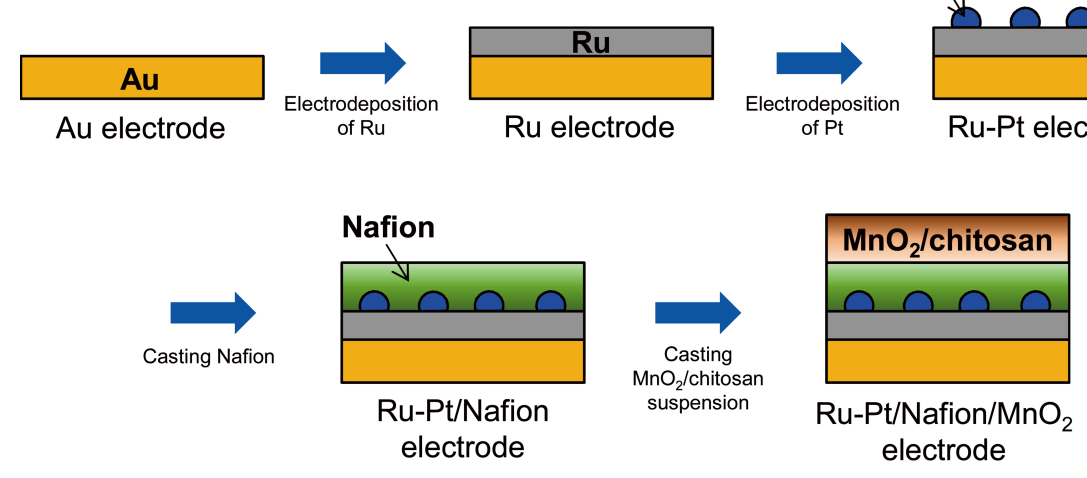

Fig. 1 Schematic illustration of the fabrication of a Pt-Ru/ $\mathrm{Nafion} / \mathrm{MnO}_{2}$ electrode.

$5 \mathrm{wt} \%$ Nafion solution (Aldrich) with a mixture of 1-propanol ( $80 \mathrm{vol} \%)$ and distilled water $(20 \mathrm{vol} \%)$. The thickness of the Nafion layer was estimated by scanning electron microscopy (SEM) observation of the cross-section of a silicon wafer coated with Nafion with the same condition to be $c a .1 .5 \mu \mathrm{m}$.

$\mathrm{MnO}_{2}$ particles were prepared as follows: $1.35 \mathrm{~g}$ of $\mathrm{MnSO}_{4} \cdot \mathrm{H}_{2} \mathrm{O}$ (Aldrich) and $0.3 \mathrm{~g}$ of Pluronic F-88 (ADEKA) were added to $20 \mathrm{~mL}$ of distilled water, and the solution was magnetically stirred for $10 \mathrm{~min}$. The mixture was transferred into a flask and heated up to $90^{\circ} \mathrm{C}$. Twelve milliliters of aqueous solution containing $1.83 \mathrm{~g}$ of $\left(\mathrm{NH}_{4}\right)_{2} \mathrm{~S}_{2} \mathrm{O}_{8}$ (Wako) were then slowly added into the flask, and the mixture was heated at $90^{\circ} \mathrm{C}$ for 15 min under a stirred condition. The synthesized $\mathrm{MnO}_{2}$ particles were filtered to collect fine particles. A $\mathrm{MnO}_{2}$ suspension was prepared by adding $\mathrm{MnO}_{2}(48 \mathrm{mg})$ and chitosan $(30 \mathrm{mg})$, as a binder, into a mixture of distilled water $(4.0 \mathrm{~mL})$, 1-propanol $(5.9 \mathrm{~mL})$ and acetic acid $(0.1 \mathrm{~mL})$.

A Pt-Ru/Nafion/ $\mathrm{MnO}_{2}$ electrode was prepared first by casting a $7.1 \mu \mathrm{L} \mathrm{cm} \mathrm{cm}^{-2}$ of $1 \mathrm{wt} \%$ Nafion solution on a Pt-Ru electrode. The Nafion-coated Pt-Ru electrode was soaked in $10 \mu \mathrm{M} \mathrm{NaOH}$ to exchange protons with the sulfonyl groups of Nafion, creating $-\mathrm{SO}_{3}{ }^{-}$groups. Then a $35.4 \mu \mathrm{L} \mathrm{cm}{ }^{-2} \mathrm{MnO}_{2}$ suspension was cast on the Nafion-coated Pt-Ru electrode to obtain a $\mathrm{Pt}-\mathrm{Ru} / \mathrm{Nafion} / \mathrm{MnO}_{2}$ electrode after drying. From the cross-sectional SEM image of Nafion/ $\mathrm{MnO}_{2}$-coated silicon wafer, the thickness of the Nafion and the $\mathrm{MnO}_{2}$ layers was estimated to be $c a .1$ and $3 \mu \mathrm{m}$, respectively.

\section{Amperometric detection of $\mathrm{CO}$}

Amperometric detection of $\mathrm{CO}$ and other model interferents (UA, AA and HP) was carried out using a three-electrode electrochemical cell equipped with a $\mathrm{Pt}$ wire and a $\mathrm{Ag} / \mathrm{AgCl}$ electrode as counter and reference electrodes, respectively, connected to a potentiostat (HZ-5000, Hokuto Denko). For amperometric measurement, the electrode was held at $+520 \mathrm{mV}$ vs. $\mathrm{Ag} / \mathrm{AgCl}$ in saline (Otsuka Pharmaceutical): after the current stabilized, CO-containing argon (CO/Ar) gas (1000, 3000, 5000 or $10000 \mathrm{ppm}$ ) was bubbled into the saline or an aliquot of a model interferent solution was added into the saline using a microsyringe. The $\mathrm{CO} / \mathrm{Ar}$ gas was purchased from Takachiho Trading Co., Ltd. According to Henry's law, if one considers the vapor pressure of water to be 23.8 Torr and the solubility of $\mathrm{CO}$ to be $2.3 \mathrm{~mL} / 100 \mathrm{~mL}$ in water at $25^{\circ} \mathrm{C}$, the saturating concentrations of $\mathrm{CO}$ in the bubbled saline were calculated to be $0.9,2.7,4.5$ and $9.0 \mu \mathrm{M}$ for the 1000, 3000, 5000 and 10000 ppm CO/Ar gases, respectively.

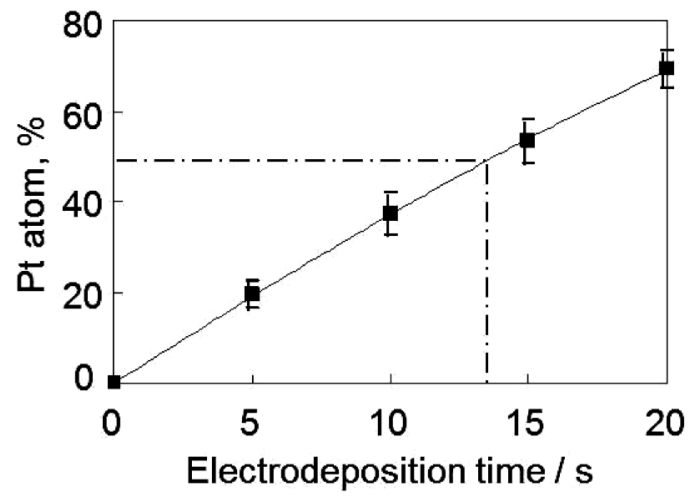

Fig. 2 Relationship between atomic concentration ratio of $\mathrm{Pt}$ on the $\mathrm{Pt}-\mathrm{Ru}$ electrode surface and electrodeposition time of $\mathrm{Pt}$ on the $\mathrm{Ru}$ electrode.

\section{Results and Discussion}

Preparation and $\mathrm{CO}$ detection properties of Pt-Ru electrode Initially, a ruthenium thin film was formed on a gold electrode by electrodeposition using $20 \mathrm{mM} \mathrm{RuCl}{ }_{3}$ at a potential of $-500 \mathrm{mV} v s . \mathrm{Ag} / \mathrm{AgCl}$ at $40^{\circ} \mathrm{C}$ for $180 \mathrm{~s}$. With this procedure, the gold surface was covered fully by the ruthenium thin film: the coverage was confirmed by the Au $4 \mathrm{f}$ peak disappearing in the XPS of the gold wire after ruthenium deposition with the same condition (result not shown). Then, platinum particles were deposited on the ruthenium thin film by electrodeposition. We then investigated the relationship between the $\mathrm{Pt} / \mathrm{Ru}$ ratio and the electrodeposition time for Ru deposition. The ratio was calculated from XPS quantitative analysis using peak areas for $\mathrm{Pt} 4 \mathrm{f}$ and $\mathrm{Ru} 3 \mathrm{p}$. The $\mathrm{Pt} / \mathrm{Ru}$ ratio was found to show a linear increase as the deposition time increased (Fig. 2). Based on this result, we determined the deposition time of the Pt deposition to be $14 \mathrm{~s}$ for fabrication of a Pt-Ru electrode with a Pt/Ru ratio of unity, which had been reported to be the most active for methanol oxidation and hence for $\mathrm{CO}$ oxidation at Pt-Ru alloy catalysts. $^{14,15}$ Figure 3 shows XPS Pt $4 \mathrm{f}$ and Ru 3p spectra of a Pt-Ru electrode $(\mathrm{Pt} / \mathrm{Ru}=1)$. The peak position of the $\mathrm{Pt}$ 4f spectrum indicated a binding energy more positive by $0.4-0.5 \mathrm{eV}$ than that of pure platinum. This should be due to an increased $5 \mathrm{~d}$ vacancy of $\mathrm{Pt}$ by $\mathrm{Ru}$ on the $\mathrm{Pt}-\mathrm{Ru}$ electrode, which is considered to decrease the back donation from Pt $5 \mathrm{~d}$ 
(a) Pt 4f



Binding energy / eV (b) Ru 3p

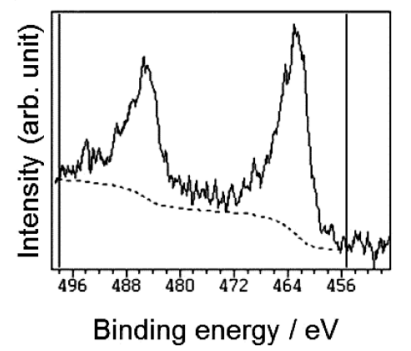

Fig. 3 XPS (a) Pt 4f and (b) Ru 3p core level spectra of the Pt-Ru electrode. Electrodeposition time for Pt deposition was $14 \mathrm{~s}$.

(a)



(b)

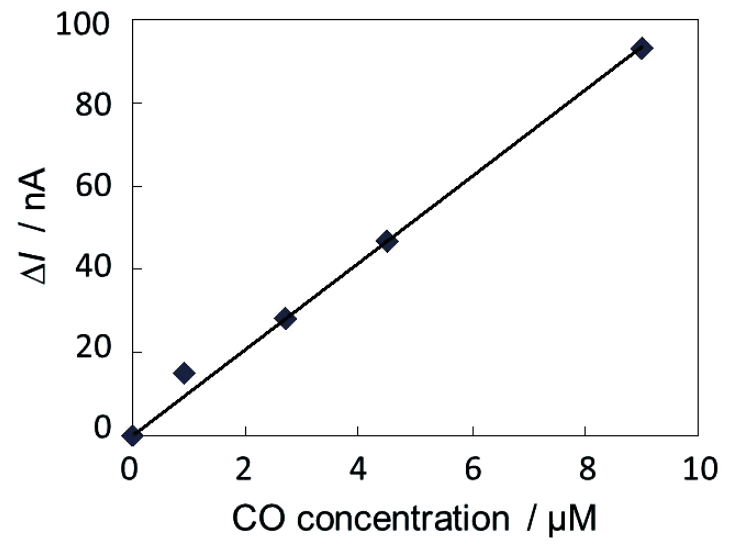

Fig. 4 (a) Amperometric current response to $\mathrm{CO}$ bubbling in saline at the Pt-Ru electrode. The arrow sign indicates the time when the bubbling started. (b) Calibration curve for amperometric $\mathrm{CO}$ detection at the Pt-Ru electrode.

orbital to $\mathrm{CO} 2 \pi^{*}$ orbital, contributing to the chemisorption of $\mathrm{CO}$ onto the Pt surface. ${ }^{24,25}$

Amperometric detection of $\mathrm{CO}$ with various concentrations in saline is shown in Fig. 4a. The response current started to increase immediately after the $\mathrm{CO}$ gas bubbling started, followed by saturation of the current after $50-250 \mathrm{~s}$. The lag between the times when the bubbling started and when the current reached its saturation should be because of the time needed for saturation of concentration of the dissolving $\mathrm{CO}$ in the solution, which is inevitable in this study. The current was rather stable after the saturation, confirming that the Pt-Ru system was

Table 1 Current response to $\mathrm{CO}$ and model interferents $(\Delta I)$ at $\mathrm{Pt}-\mathrm{Ru}, \mathrm{Pt}-\mathrm{Ru} / \mathrm{Nafion}$ and $\mathrm{Pt}-\mathrm{Ru} / \mathrm{Nafion} / \mathrm{MnO}_{2}$ electrodes, and selectivity indeces $\left(S_{\mathrm{CO}}\right)$

\begin{tabular}{|c|c|c|c|c|c|c|c|}
\hline \multirow{2}{*}{ Electrode } & \multicolumn{4}{|c|}{$\Delta I / \mathrm{nA} \mathrm{cm}^{-2 \mathrm{a}}$} & \multicolumn{3}{|c|}{$S_{\mathrm{CO}^{\mathrm{b}}}$} \\
\hline & $\mathrm{CO}$ & UA & AA & HP & UA & $\mathrm{AA}$ & HP \\
\hline $\mathrm{Pt}-\mathrm{Ru}$ & 4650 & 660 & 1115 & 165 & 0.88 & 0.81 & 0.76 \\
\hline Pt-Ru/Nafion & 3130 & 60 & 30 & 190 & 0.98 & 0.99 & 0.62 \\
\hline $\mathrm{Pt}-\mathrm{Ru} / \mathrm{Nafion} / \mathrm{MnO}_{2}$ & 1760 & 25 & 30 & 0 & 0.99 & 0.98 & 1.00 \\
\hline
\end{tabular}

a. Concentration of $\mathrm{CO}, \mathrm{UA}$ and AA was $9 \mu \mathrm{M}$, and concentration of HP was $1 \mu \mathrm{M}$.

b. Definition of $S_{\mathrm{CO}}$ is indicated in Eq. (1) in the text.

(a)

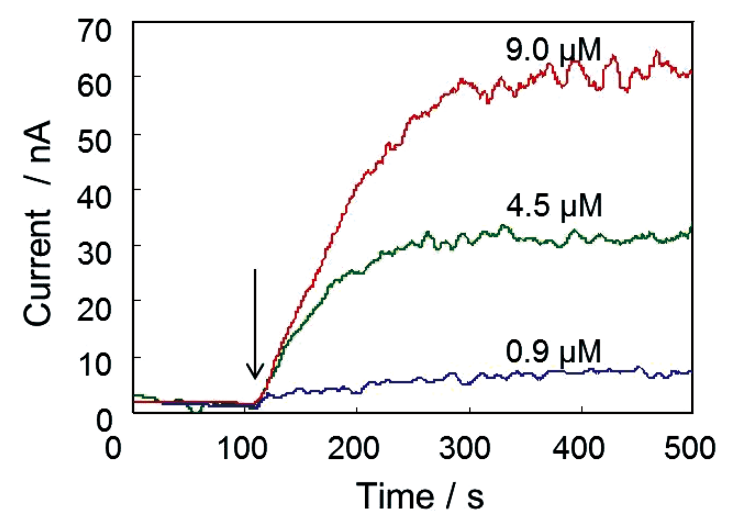

(b)

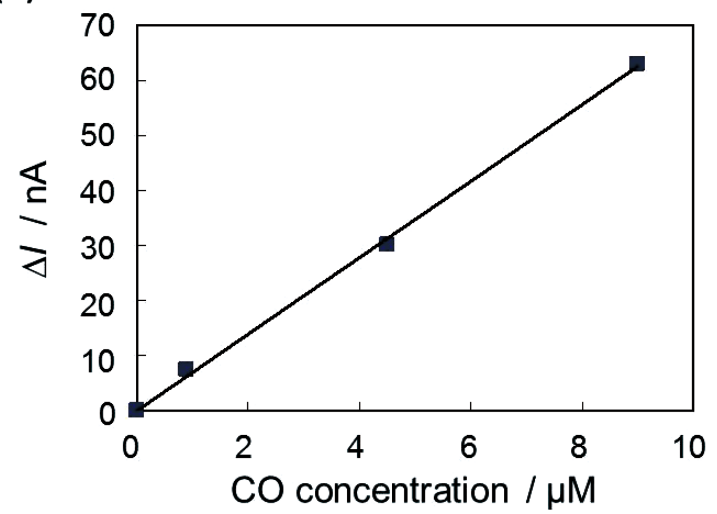

Fig. 5 (a) Amperometric current response to $\mathrm{CO}$ bubbling in saline at the Pt-Ru/Nafion electrode. The arrow sign indicates the time when the bubbling started. (b) Calibration curve for amperometric $\mathrm{CO}$ detection at the Pt-Ru/Nafion electrode.

tolerant to $\mathrm{CO}$ poisoning. The current increment at the saturation $\left(\Delta I_{\mathrm{CO}}\right)$ was found to be directly proportional to the calculated $\mathrm{CO}$ concentration in the solution from 0.9 to $9 \mu \mathrm{M}$ with a slope of $520 \mathrm{nA} \mathrm{cm}^{-2} \mu \mathrm{M}^{-1}$ (Fig. $4 \mathrm{~b}$ ). Vreman has determined the CO concentration in rodent tissues to be in the range of $1-10 \mathrm{pmol} \mathrm{mg}^{-1}$ (or $1-10 \mu \mathrm{M}$ ), and $c a .45 \mathrm{pmol} \mathrm{mg}^{-1}$ (or $45 \mu \mathrm{M})$ in rodent blood. ${ }^{26}$ Thus, this result indicates that the $\mathrm{Pt}-\mathrm{Ru}$ electrode can be applied to the electrochemical $\mathrm{CO}$ detection, and should be useful for quantitative determination of $\mathrm{CO}$ at physiological concentrations in vivo. In order to estimate the selectivity of the Pt-Ru electrode of $\mathrm{CO}$ to other possible interferents in vivo, we also carried out amperometric detection 

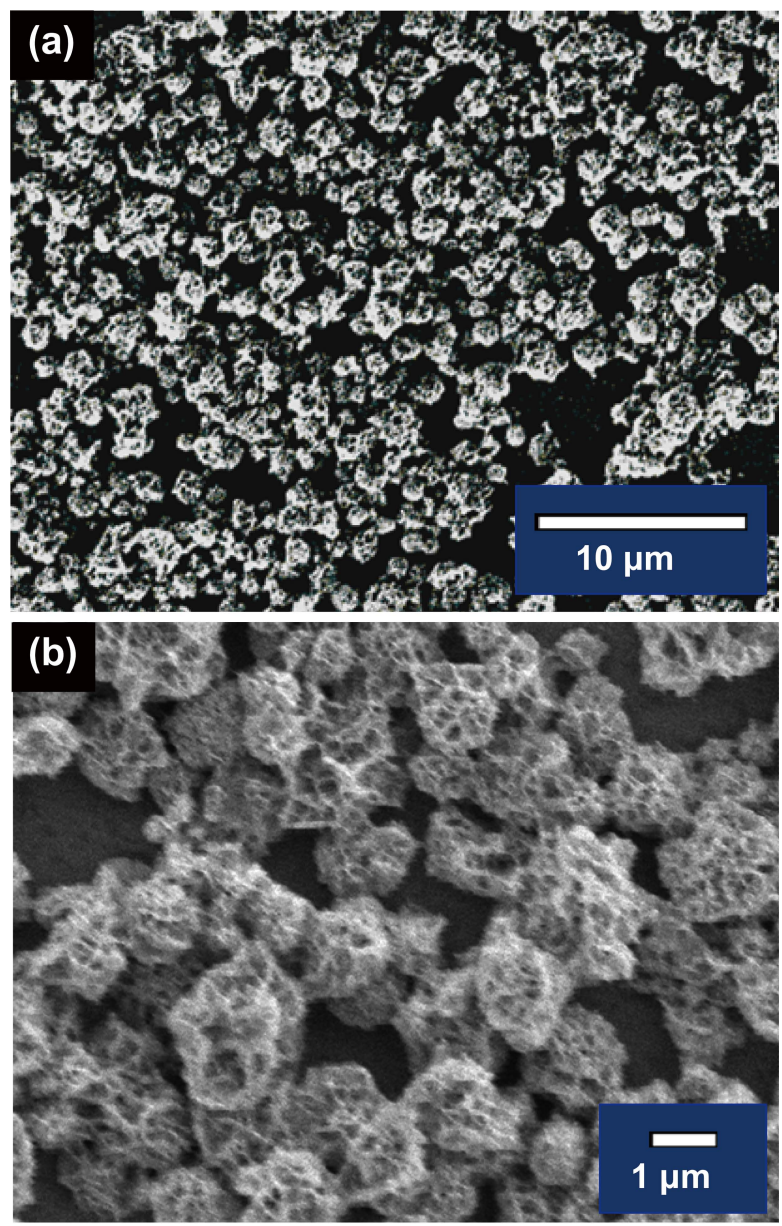

Fig. 6 SEM image of the $\mathrm{MnO}_{2}$ particles. (b) Magnified image of (a).

examinations for UA, AA and HP. The current increment $(\Delta I)$ for $9 \mu \mathrm{M} \mathrm{UA}, 9 \mu \mathrm{M}$ AA and $1 \mu \mathrm{M} \mathrm{HP}$ is compared with $\Delta I_{\mathrm{CO}}$ at the corresponding concentrations in Table 1. A selectivity index $\left(S_{\mathrm{CO}}\right)$ defined as Eq. (1) is also listed in Table 1.

$$
S_{\mathrm{CO}}=\Delta I_{\mathrm{CO}} /\left(\Delta I_{\mathrm{CO}}+\Delta I_{\mathrm{i}}\right)
$$

where $\Delta I_{\mathrm{i}}$ is $\Delta I$ for the interferent (UA, AA or HP) at the same concentration to $\mathrm{CO}$. Although the $\Delta I_{\mathrm{i}}$ values for these model interferents were smaller than the $\Delta I_{\mathrm{CO}}$, results revealed that the electrode should be further modified to improve the selectivity to $\mathrm{CO}$.

\section{Nafion-coated Pt-Ru electrode}

In order to improve the selectivity to electrochemical detection of $\mathrm{CO}$, we coated a Nafion thin film onto the Pt-Ru electrode surface. By the investigation with different concentrations of Nafion cast solution from 0.5 to $5 \mathrm{wt} \%$, good selectivity to CO detection was found to be obtained at the concentration of $1-2 \mathrm{wt} \%$. Figure 5a shows current response to $\mathrm{CO}$ bubbling in saline at a Nafion-covered Pt-Ru electrode using $2 \mathrm{wt} \%$ Nafion solution (Pt-Ru/Nafion electrode). Although the $\Delta I_{\mathrm{CO}}$ was somewhat smaller than that obtained at a Pt-Ru electrode, the current response still showed good linearity to $\mathrm{CO}$ concentration up to $9 \mu \mathrm{M}$ with a slope of $347 \mathrm{nA} \mathrm{cm}^{-2} \mu \mathrm{M}^{-1}$ (Fig. 5b). $\Delta I_{\mathrm{UA}}$ and $\Delta I_{\mathrm{AA}}$ were found to decrease remarkably by the coating with Nafion from 660 and 1115 to 60 and $30 \mathrm{nA} \mathrm{cm}^{-2}$ at $9 \mu \mathrm{M}$,

\section{(a) Mn 2p}

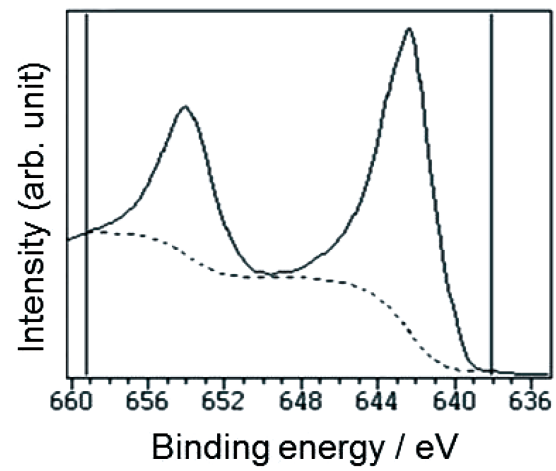

(b) Mn 3s

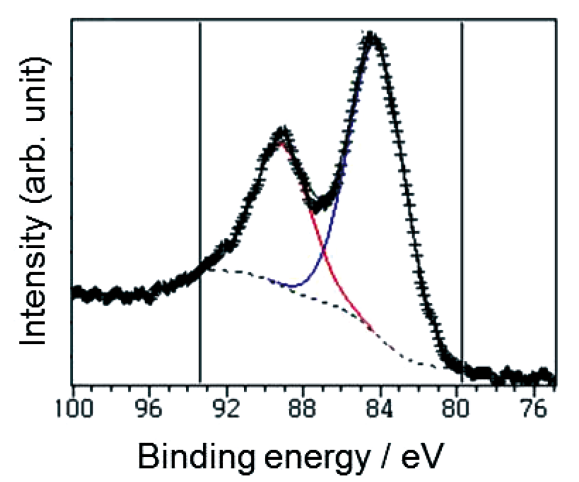

(c) $01 \mathrm{~s}$

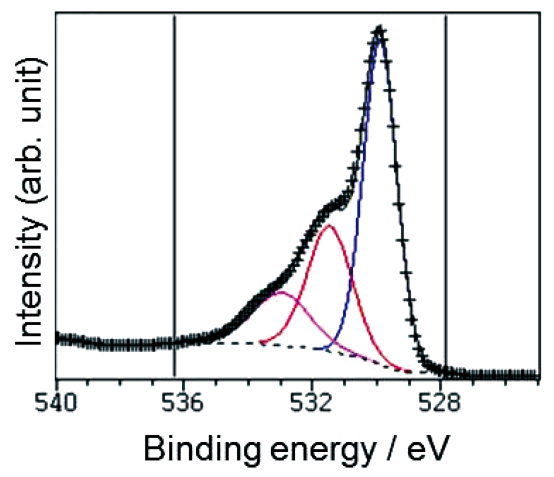

Fig. 7 XPS (a) Mn 2p, (b) Mn 3s and (c) O 1s core level spectra of the $\mathrm{MnO}_{2}$ particle.

respectively (Table 1). It should be due to the electrostatic repulsion between the anionic $-\mathrm{SO}_{3}{ }^{-}$groups of Nafion and the anionic molecules (UA and AA). ${ }^{19,20}$ Although modification with Nafion could improve the selectivity of $\mathrm{CO}$ at the Pt-Ru electrode from UA and AA, it was not effective for minimizing the current response due to HP.

\section{Preparation of $\mathrm{MnO}_{2}$ particles and its application to selective} CO sensing

In order to suppress the current response to HP, we immobilized $\mathrm{MnO}_{2}$ onto the modified Pt-Ru electrode surface. $\mathrm{MnO}_{2}$ particles were characterized by SEM, X-ray diffraction (XRD) and XPS. From the SEM observation of the $\mathrm{MnO}_{2}$ particles in the suspension, the particle diameter was found to be around $1 \mu \mathrm{m}$ (Fig. 6). Because no XRD pattern for $\mathrm{MnO}_{2}$ crystal was observed (result not shown), the particle was considered to consist of amorphous $\mathrm{MnO}_{2}$. Figure 7 shows XPS Mn 2p, Mn 3s 
Table 2 XPS data of the $\mathrm{MnO}_{2}$ particle

\begin{tabular}{|c|c|c|c|c|c|c|c|}
\hline \multirow{2}{*}{ Sample } & \multirow{2}{*}{$\frac{\mathrm{Mn} 2 \mathrm{p}_{3 / 2}}{E_{\mathrm{b}} / \mathrm{eV}}$} & \multicolumn{3}{|c|}{$\mathrm{Mn} 3 \mathrm{~s}$} & \multicolumn{2}{|c|}{$\mathrm{O} 1 \mathrm{~s}$} & \multirow{2}{*}{$\begin{array}{c}E_{\mathrm{b}}(\mathrm{Mn} 3 \mathrm{~s})-E_{\mathrm{b}}(\mathrm{O} 1 \mathrm{~s}) \\
\mathrm{eV}\end{array}$} \\
\hline & & $E_{\mathrm{b}, 1} / \mathrm{eV}$ & $E_{\mathrm{b}, 2} / \mathrm{eV}$ & $\Delta E_{\mathrm{b}} / \mathrm{eV}$ & $E_{\mathrm{b}} / \mathrm{eV}$ & Area, $\%$ & \\
\hline \multirow[t]{3}{*}{$\mathrm{MnO}_{2}{ }^{\mathrm{a}}$} & 642.30 & 84.19 & 899.08 & 4.89 & 529.9 & 55.9 & 112.39 \\
\hline & & & & & 531.5 & 28.8 & \\
\hline & & & & & 533.0 & 15.3 & \\
\hline \multirow[t]{3}{*}{$\mathrm{MnO}_{2}{ }^{\mathrm{b}}$} & 642.40 & 83.80 & 88.72 & 4.92 & 529.7 & 64.8 & 112.7 \\
\hline & & & & & 531.0 & 20.7 & \\
\hline & & & & & 532.4 & 14.5 & \\
\hline $\mathrm{MnO}^{\mathrm{c}}$ & 641.12 & 83.37 & 89.16 & 5.79 & 529.83 & & 111.29 \\
\hline $\mathrm{Mn}_{3} \mathrm{O}_{4}{ }^{\mathrm{c}}$ & 641.62 & 83.36 & 88.86 & 5.50 & 530.09 & & 111.53 \\
\hline $\mathrm{Mn}_{2} \mathrm{O}_{3} \mathrm{c}$ & 641.40 & 83.36 & 88.77 & 5.41 & 529.67 & & 111.73 \\
\hline $\mathrm{MnO}_{2}{ }^{\mathrm{c}}$ & 641.85 & 83.92 & 88.70 & 4.78 & 529.48 & & 112.37 \\
\hline
\end{tabular}

a. This study. b. Data from Ref. 24. c. Data of authentic samples from Ref. 25.

and $\mathrm{O} 1 \mathrm{~s}$ spectra of the $\mathrm{MnO}_{2}$ particles. The splitting of the Mn 3s peak (Fig. 7b) is known to be useful for determining the oxidation state of manganese. The peak separation of electrons in the core level with unpaired electrons in the valence band level is caused by the electron exchange interaction upon photoelectron ejection. ${ }^{27}$ The difference of the peak position $\left(\Delta E_{\mathrm{b}}\right)$ varies among types of manganese oxides $\left(\mathrm{MnO}, \mathrm{Mn}_{3} \mathrm{O}_{4}\right.$, $\mathrm{Mn}_{2} \mathrm{O}_{3}$ and $\mathrm{MnO}_{2}$ ). $\Delta E_{\mathrm{b}}$ of the $\mathrm{MnO}_{2}$ particles prepared in this study was $4.89 \mathrm{eV}$ and this value was consistent with that in the literature $(4.78 \mathrm{eV})$ (Table 2). ${ }^{27,28}$ Differences in the peak positions between the $\mathrm{Mn} 2 \mathrm{p}_{3 / 2}$ peak and the $\mathrm{O} 1 \mathrm{~s}$ peak (the component with the lowest binding energy) were also consistent with that for $\mathrm{MnO}_{2}$ in the literature. In addition, $\mathrm{Mn} / \mathrm{O}$ atomic concentration ratio was estimated to be $\sim 0.5$ by quantitative analysis with XPS. Thus we conclude that the product was $\mathrm{MnO}_{2}$ particles. The $\mathrm{O} 1 \mathrm{~s}$ spectra could be deconvoluted into three bands (Fig. 7c). These bands were assigned to be Mn-O-Mn (529.9 eV), Mn-O-H (531.5 eV, surface hydroxide) and $\mathrm{H}-\mathrm{O}-\mathrm{H}(533.0 \mathrm{eV}$, water molecule) components, and were also consistent with the result in Chigane's report. ${ }^{27}$

Figure 8a shows amperometric current response for $\mathrm{CO}$ detection at a $\mathrm{MnO}_{2}$-modified $\mathrm{Pt}-\mathrm{Ru} / \mathrm{Nafion}$ electrode (Pt-Ru/ Nafion/ $/ \mathrm{MnO}_{2}$ electrode). The detection current for $\mathrm{CO}$ was found to decrease after the $\mathrm{MnO}_{2}$ modification. This should be due to a decrease of the mass-transfer rate of the dissolving $\mathrm{CO}$ at the electrode/electrolyte interface due to the modification. Beyond that, however, the current response to HP was suppressed almost completely (Table 1). $\mathrm{MnO}_{2}$ is a well-known catalyst for the decomposition of $\mathrm{HP}$ into $\mathrm{H}_{2} \mathrm{O}$ and $\mathrm{O}_{2}$ :

$$
2 \mathrm{H}_{2} \mathrm{O}_{2} \longrightarrow 2 \mathrm{H}_{2} \mathrm{O}+\mathrm{O}_{2}
$$

Since $\mathrm{MnO}_{2}$ itself is an insulating material, loading too much of it should cause a small current response to $\mathrm{CO}$ due to a decrease in the mass-transfer rate. Thus, the amount of $\mathrm{MnO}_{2}$ particles loaded is important as regards the selectivity and sensitivity of $\mathrm{CO}$ detection. The amount of $\mathrm{MnO}_{2}$ in this study was optimized as the lowest loading, with almost no current observed for $1 \mu \mathrm{M}$ HP. The current response to $\mathrm{CO}$ concentration was still linear in the range up to $9 \mu \mathrm{M}$ with the slope of $173 \mathrm{nA} \mathrm{cm}^{-2} \mu \mathrm{M}^{-1}$ (Fig. 8b). Finally, sensitive electrochemical detection of $\mathrm{CO}$ was achieved at a Pt-Ru/Nafion/ $/ \mathrm{MnO}_{2}$ electrode, at which current response for model interferents: UA, AA and HP was highly suppressed to below $1.7 \%$ at the same concentration of $\mathrm{CO}$. (a)



(b)

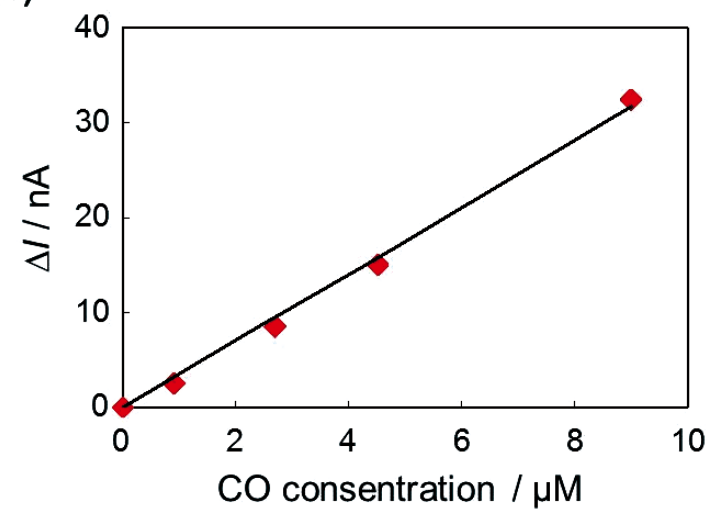

Fig. 8 (a) Amperometric current response to $\mathrm{CO}$ bubbling in saline at the $\mathrm{Pt}-\mathrm{Ru} / \mathrm{Nafion} / \mathrm{MnO}_{2}$ electrode. The arrow sign indicates the time when the bubbling started. (b) Calibration curve for amperometric $\mathrm{CO}$ detection at the $\mathrm{Pt}-\mathrm{Ru} / \mathrm{Nafion} / \mathrm{MnO}_{2}$ electrode.

\section{Conclusions}

A Pt-Ru/Nafion/ $\mathrm{MnO}_{2}$ electrode was fabricated for selective electrochemical detection of $\mathrm{CO}$ at physiological concentrations. By choosing the duration time for the electrodeposition of platinum on a ruthenium electrode surface, an electrode material for sensitive detection of $\mathrm{CO}$ was fabricated. In addition, modifying the Pt-Ru electrode surface with a Nafion layer 
followed by loading a $\mathrm{MnO}_{2}$ particle layer led to improvement of selectivity to $\mathrm{CO}$ detection against model interferents: UA, AA and HP. At the Pt-Ru/Nafion/ $\mathrm{MnO}_{2}$ electrode, the sensitivity of $\mathrm{CO}$ detection was $173 \mathrm{nA} \mathrm{cm}^{-2} \mu \mathrm{M}^{-1}$ in the range up to $9 \mu \mathrm{M}$, and current response to UA and AA was reduced to 3.8 and $2.7 \%$ of that at the unmodified electrode, respectively, and that to HP was suppressed below noise level. Thus, the $\mathrm{Pt}-\mathrm{Ru} / \mathrm{Nafion} / \mathrm{MnO}_{2}$ electrode should be useful for quantitative and real-time analysis of $\mathrm{CO}$ in vivo, which should be of significant benefit to physiological and therapeutic studies of CO.

\section{Acknowledgements}

The authors thank Mr. John McDonough, Drexel University, for reviewing the manuscript.

\section{References}

1. M. Suematsu, Y. Wakabayashi, and Y. Ishimura, Cardiovasc. Res., 1996, 32, 679.

2. L. E. Otterbein, F. H. Bach, J. Alam, M. Soares, H. Tao Lu, M. Wysk, R. J. Davis, R. A. Flavell, and A. M. K. Choi, Nat. Med., 2000, 6, 422.

3. S. Brouard, L. E. Otterbein, J. Anrather, E. Tobiasch, F. H. Bach, A. M. K. Choi, and M. P. Soares, J. Exp. Biol., 2000, 192, 1015.

4. T.-S. Lee and L.-Y. Chau, Nat. Med., 2002, 8, 240.

5. B. Sun, Z. Sun, Q. Jin, and X. Chen, Int. J. Biol. Sci., 2008, 4, 176.

6. A. Nakao, R. Sugimoto, T. R. Billiar, and K. R. McCurry, J. Clin. Biochem. Nutr., 2009, 44, 1.

7. R. Motterlini and L. E. Otterbein, Nat. Rev. Drug Discovery, 2010, 9, 728.

8. K. Uchiyama, Y. Naito, T. Takagi, K. Mizushima, N. Hayashi, A. Harusato, I. Hirata, T. Omatsu, O. Handa, T. Ishikawa, N. Yagi, S. Kokura, and T. Yoshikawa, Biochem. Biophys. Res. Commun., 2010, 391, 1122.

9. D. E. Stec, T. Vera, M. V. Storm, G. R. McLemore, and M.
J. Ryan, Am. J. Physiol.-Regul. Integr. Comp. Physiol., 2009, 297, R1822.

10. H. S. Kim, P. A. Loughran, and T. R. Billiar, Nitric Oxide, 2008, 18, 256.

11. H. Youn, R. L. Kerby, and G. P. Roberts, J. Biol. Chem., 2004, 279, 45744.

12. H. Youn, M. Conrad, S.-Y. Chung, and G. P. Roberts, Biochem. Biophys. Res. Commun., 2006, 348, 345.

13. H. Nitta, M. Kinoyama, F. Teramoto, A. Watanabe, H. Koga, K. Haruma, R. Akagi, and H. Ueda, Clin. Exp. Med., 2007, 7, 77.

14. M. Watanabe and S. Motoo, J. Electroanal. Chem., 1975, 60,275

15. M. Watanabe, M. Uchida, and S. Motoo, J. Electroanal. Chem., 1987, 229, 395.

16. M. Wakisaka, S. Mitsui, Y. Hirose, K. Kawashima, H. Uchida, and M. Watanabe, J. Phys. Chem. B, 2006, 110, 23489.

17. T. Yajima, H. Uchida, and M. Watanabe, J. Phys. Chem. B, 2004, 108, 2654.

18. P. Waszczuk, G. Q. Lu, A. Wieckowski, C. Lu, C. Rice, and R. I. Masel, Electrochim. Acta, 2002, 47, 3637.

19. J.-M. Zen and I. L. Chen, Electroanalysis, 1997, 9, 537.

20. L. S. Rocha and H. M. Carapuça, Bioelectrochemistry, 2006, 69, 258.

21. X. Kang, J. Wang, Z. Tang, H. Wu, and Y. Lin, Talanta, 2009, 78, 120.

22. X. Sun, Y. Zhang, H. Shen, and N. Jia, Electrochim. Acta, 2010, 56, 700 .

23. G. Shen, C. Cai, and J. Yang, Electrochim. Acta, 2011, 56, 8272.

24. M. Watanabe, Y. Zhu, H. Igarashi, and H. Uchida, Electrochemistry, 2000, 68, 244.

25. H. Igarashi, T. Fujino, Y. Zhu, H. Uchida, and M. Watanabe, Phys. Chem. Chem. Phys., 2001, 3, 306.

26. H. J. Vreman, R. J. Wong, T. Kadotani, and D. K. Stevenson, Anal. Biochem., 2005, 341, 280.

27. M. Chigane and M. Ishikawa, J. Electrochem. Soc., 2000, 147, 2246.

28. M. Toupin, T. Brousse, and D. Bélanger, Chem. Mater., 2004, 16, 3184. 